\title{
Agrobacterium-Mediated Gene Transfer to Cereal Crop Plants: Current Protocols for Barley, Wheat, Triticale, and Maize
}

\author{
Goetz Hensel, ${ }^{1}$ Christine Kastner, ${ }^{1}$ Sylwia Oleszczuk, ${ }^{1,2}$ Jan Riechen, ${ }^{1}$ and Jochen Kumlehn' \\ ${ }^{1}$ Plant Reproductive Biology, Leibniz Institute of Plant Genetics and Crop Plant Research (IPK), Corrensstraße 3, \\ 06466 Gatersleben, Germany \\ ${ }^{2}$ Plant Breeding and Acclimatization Institute, Radzików, 05-870 Blonie, Poland
}

Correspondence should be addressed to Goetz Hensel, hensel@ipk-gatersleben.de

Received 8 April 2009; Accepted 17 April 2009

Recommended by Hikmet Budak

The development of powerful "omics" technologies has enabled researchers to identify many genes of interest for which comprehensive functional analyses are highly desirable. However, the production of lines which ectopically express recombinant genes, or those in which endogenous genes are knocked down via stable transformation, remains a major bottleneck for the association between genetics and gene function in monocotyledonous crops. Methods of effective DNA transfer into regenerable cells of immature embryos from cereals by means of Agrobacterium tumefaciens have been modified in a stepwise manner. The effect of particular improvement measures has often not been significantly evident, whereas their combined implementation has resulted in meaningful advances. Here, we provide updated protocols for the Agrobacterium-mediated generation of stably transgenic barley, wheat, triticale and maize. Based upon these methods, several hundred independent transgenic lines have been delivered, with efficiencies of inoculated embryos leading to stably transgenic plants reaching $86 \%$ in barley, $10 \%$ in wheat, $4 \%$ in triticale, and $24 \%$ in maize.

Copyright (C) 2009 Goetz Hensel et al. This is an open access article distributed under the Creative Commons Attribution License, which permits unrestricted use, distribution, and reproduction in any medium, provided the original work is properly cited.

\section{Introduction}

Cereals such as barley, wheat, triticale and maize play a pivotal role for the nutritional intake of humans, being such via direct utilisation as food or through livestock breeding. For 2007, the FAO estimated a global production of some $700 \mathrm{Mt}$ of maize, over $600 \mathrm{Mt}$ of wheat, $137 \mathrm{Mt}$ of barley and $13 \mathrm{Mt}$ of triticale [1]. This data may explain why these crops are a focus of research and biotechnological development.

Over the past centuries improvement of cereals was achieved mostly by conventional breeding. However, due to the ever-growing world population, limited availability of water, increasingly exhausted fossil energy resources, and the changing climatic conditions, new technologies are urgently required to cope with future challenges. Since the mid 1990s, genetic engineering of cereals has provided a novel field of opportunities for faster and more directed modification or introduction of agronomically useful traits [2-6]. While the first successful genetic transformation events in cereal species had been based on direct gene transfer, which was associated with a number of disadvantages, the pioneering study of Hiei et al. [7] on Agrobacterium-mediated transformation of rice represents another milestone. They generated many independent transgenic plants, with T-DNA being stably integrated in the nuclear genome, and the transgenes were shown to be expressed. Ishida and colleagues [8] were then the first to publish a protocol for the generation of transgenic maize, which also relied on A. tumefaciens. In the following years, similar protocols for all major cereal crops including barley [9] and wheat [10] were published.

The ability to efficiently form shoots originating from single totipotent cells is indispensible for successful genetic transformation of plants. In contrast to dicotyledonous plants, cereal crops are hardly able to regenerate plants from leaf tissue. However, other gene transfer target explants, for example, immature embryos [4], embryogenic pollen cultures [11] and isolated ovules [12] have proven useful in cereals. Agrobacterium-mediated genetic transformation of cereals has been largely confined to particular genotypes that combine the amenability to gene transfer by Agrobacterium 
with adequate regeneration potential. Besides the most suitable lines used as models in routine transformation, namely, the cv. "Golden Promise" in barley [9], Hi II hybrids in maize $[4,13]$, and the breeding line "Bobwhite 26" in wheat [10], some other genotypes have turned out to be useful for Agrobacterium-mediated transformation, albeit with significantly lower efficiency $[3,5,14-18]$. In triticale, the winter type cv. "Bogo" was shown to perform exceedingly well in plant regeneration from immature embryo explants [19-21]. However, no study has yet provided ample evidence of genomic integration of recombinant DNA by means of $A$. tumefaciens in this cereal crop species.

It is not surprising that protocols efficiently used for cereal transformation generally rely on the use of hypervirulent Agrobacterium strains such as EHA101 and EHA105 in maize [22], AGL-0 and AGL- 1 in barley and wheat $[9,18,23-$ 26] as well as hypervirulent derivatives of LBA4404 in maize, barley and wheat [11, 18, 27-29]. Hypervirulence can be mediated by accessory Vir genes that are either contained on particular Ti-plasmids [30], on so-called superbinary vectors [31], or on an additional plasmid present in the Agrobacterium clone employed [11].

Particular attention has to be paid to the binary vectors used for cereal transformation. Many binary vectors that had been developed for dicot species turned out not to be suitable for cereals, which is mainly due to inappropriate promoters and selectable marker genes. Moreover, an exceedingly high stability of the plasmids in Agrobacterium appears to be vital so as to provide an adequate proportion of transformationcompetent bacteria throughout the entire episode of cocultivation, in which there are no selective conditions in terms of the bacterial resistance mediated by the binary vector. In this regard, pVS1-based vector backbones proved particularly valuable [32]. More recently, the IPKb vector series was developed that features a number of useful plasmid elements such as pVS1, monocot-compatible promoters and selectable marker genes combined with GATEWAY-cassettes for either over-expression or RNAi-constructs. Moreover, convenient modularity is provided in terms of the selectable marker expression unit and the promoter that directs candidate gene expression [33].

A successful interaction of A. tumefaciens with the gene transfer recipient cells depends on many particular conditions. In cereals, which are at best untypical Agrobacterium hosts, deviations from optimal conditions are hardly tolerated. Influencing variables which are thought to be most crucial for gene transfer events to occur during co-cultivation include nutrient concentrations, temperature, $\mathrm{pH}$, presence and concentration of Acetosyringone and antioxidants as well as duration.

Here, we present updated Agrobacterium-based transformation protocols for barley, wheat, triticale and maize, which have been developed and successfully employed to produce hundreds of independent transgenic lines.

\section{Materials}

2.1. A. tumefaciens Strains. Transformation of barley, wheat, and triticale was mediated by a hypervirulent derivative of
A. tumefaciens strain LBA4404 [34] harbouring the binary vector pSB187 that contains the Hpt selectable marker gene driven by a $400 \mathrm{bp}$ CaMV35S-promoter, the sgfp (S65T) reporter gene [35] driven by the maize Ubi-1-promoter [36] and the vector backbone from pLH vectors [37] with its borders derived from a nopaline Ti plasmid.

In maize, gene transfer was conducted with the $A$. tumefaciens strain EHA105 [22] containing the binary vector pGH218 with the Pat gene as selectable marker and a Gus-intron reporter gene under the control of a doubled enhanced CaMV35S-promoter [38]. The vector backbone of pGH218 is the same as in pSB187.

The vector plasmids were introduced into Agrobacterium by electroporation.

2.2. Growth of Donor Plants. Germination of barley (Hordeum vulgare L.) spring type cv. "Golden Promise", wheat (Triticumaestivum L.) winter type cv. "Certo" and triticale (x Triticosecale Wittmack) winter type cv. "Bogo" grains was conducted in trays filled with a substrate mix (Spezialmischung Petuniensubstrat, Klasmann, Germany) (see Note 1) in a growth chamber $\left(14 / 12^{\circ} \mathrm{C}\right.$ day/night, 12 hours light, $136 \mu \mathrm{mol} \mathrm{s}^{-1} \mathrm{~m}^{-2}$ photon flux density). After 3 weeks small plantlets were either incubated for additional eight weeks in a vernalisation chamber with $4^{\circ} \mathrm{C}$ and 8 hours light per day, or transferred into $18-\mathrm{cm}$ pots $(2.5 \mathrm{~L})$. At the beginning of tillering stage $15 \mathrm{~g}$ Osmocote (Scotts, Netherlands) was applied per pot. Further fertilization was conducted by watering the plants fortnightly with $0.3 \%$ Hakaphos Blau (Compo, Germany). When the stems started to elongate the plants were transferred to a controlled glasshouse $\left(18 / 16^{\circ} \mathrm{C}\right.$ day/night, 16 hours light, and $170 \mu \mathrm{mol} \mathrm{s}^{-1} \mathrm{~m}^{-2}$ photon flux density). There, they were fertilized only once with $0.3 \%$ Hakaphos Grün (Compo, Germany) when the heading commenced (see Note 2).

Maize (Zea mays L.) line "Hi II" grains were grown in 9$\mathrm{cm}$ pots $(0.25 \mathrm{~L})$ containing a cultivation substrate (Substrat 2 , Klasmann, Germany) in a growth chamber $\left(22 / 20^{\circ} \mathrm{C}\right.$ day/night, 13 hours light, $170 \mu \mathrm{mol} \mathrm{s}^{-1} \mathrm{~m}^{-2}$ photon flux density). Three weeks later plantlets were transferred to a controlled glasshouse cabin $\left(25 / 17^{\circ} \mathrm{C}\right.$ day/night, 16 hours light, $170 \mu \mathrm{mol} \mathrm{s}^{-1} \mathrm{~m}^{-2}$ photon flux density) in $35-\mathrm{cm}$ pots $(20 \mathrm{~L})$ with a substrate mix and $60 \mathrm{~g}$ Osmocote Pro (Scotts, Netherlands) per pot for fertilization (see Notes 3, 4).

2.3. Plant Tissue Culture Media. The nutrient media used are summarised in Table 1. According to the protocols, precultivation media (PCM), pretreatment medium (PTM), infection medium (IM), liquid or solid co-culture media (CCM) as well as solid media for callus induction (CIM) and regeneration (RM) are required. PCM, PTM, CCM and CIM used in barley, wheat and triticale are based on MS mineral salts [39] supplemented with additional components as shown in Table 1. The RM medium is based on K4N medium which was published elsewhere [11]. In maize IM, CCM and CIM are based on Chu N6 mineral salts [40], and RM is based on MS mineral salts [39] supplemented with additional components as shown in Table 1. The $\mathrm{pH}$ was adjusted prior to filter sterilisation of the solutions. 
TABLE 1: Details on the transformation procedures and the materials needed in barley, wheat, triticale and maize. MS (Murashige and Skoog, for example, Duchefa no. M0221), K4N [11], B5 (Gamborg B5 Vitamin Mixture, e.g., Duchefa no. G0415), Hygromycin (Hygromycin B, e.g., Roche no. 10843555001), IEs-immature embryos. In cases where it is necessary to distinguish different medium compositions, the generic abbreviations of media (PCM, CCM, CIM and RM) are preceeded by a capital letter (B for barley, W for wheat, T for triticale and M for maize) representing the species for which a particular medium has been initially developed.

\begin{tabular}{|c|c|c|c|c|}
\hline Treatment/Step & Barley & Wheat & Triticale & Maize \\
\hline $\begin{array}{l}\text { Embryo } \\
\text { precultivation }\end{array}$ & - & 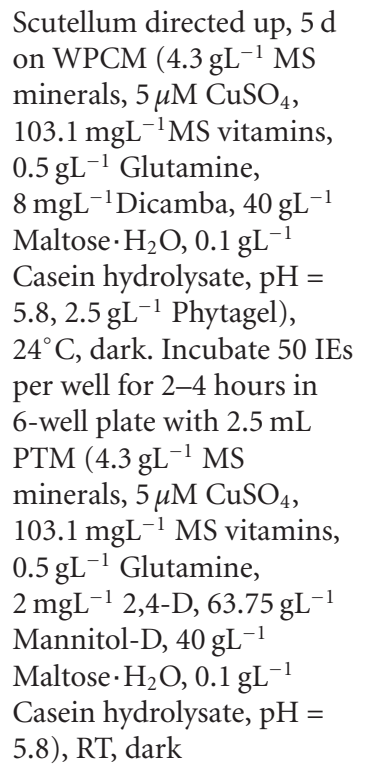 & $\begin{array}{l}\text { Scutellum directed up, } 5 \mathrm{~d} \\
\text { on TPCM }\left(4.3 \mathrm{gL}^{-1} \mathrm{MS}\right. \\
\text { minerals, } 103.1 \mathrm{mgL}^{-1} \mathrm{MS} \\
\text { vitamins, } 0.5 \mathrm{gL}^{-1} \\
\text { Glutamine, } 6.6 \mathrm{mgL}^{-1} \\
\text { Dicamba, } 15 \mathrm{gL}^{-1} \mathrm{Glucose} \text {, } \\
15 \mathrm{gL}^{-1} \text { Sucrose, } 200 \mu \mathrm{M} \\
\text { Acetosyringone, } 0.1 \mathrm{gL}^{-1} \\
\text { Casein hydrolysate, } \mathrm{pH}= \\
\left.5.2,2.5 \mathrm{gL}^{-1} \text { Phytagel }\right), \\
24^{\circ} \mathrm{C} \text {, dark }\end{array}$ & - \\
\hline
\end{tabular}

30-50 IEs in a 6-well plate

with $2.5 \mathrm{~mL}$ BCCM

(4.3 $\mathrm{gL}^{-1} \mathrm{MS}$ minerals, $1 \mathrm{mgL}^{-1}$ Thiamine $\mathrm{HCl}$, $0.8 \mathrm{gL}^{-1}$ L-Cysteine, $0.69 \mathrm{gL}^{-1}$ L-Proline, $2.5 \mathrm{mgL}^{-1}$ Dicamba, $30 \mathrm{gL}^{-1}$ Maltose $\cdot \mathrm{H}_{2} \mathrm{O}$,

Inoculation $500 \mu \mathrm{M}$ Acetosyringone, $1 \mathrm{gL}^{-1}$ Casein hydrolysate, $0.25 \mathrm{gL}^{-1}$ Myo-inositol, $\mathrm{pH}$ = 5.8) each. Remove BCCM and add $600 \mu \mathrm{L}$ Agrobacterium $\mathrm{OD}_{600}=$ 2-2.5, 1 minute 500 mbar, 10 minutes resting at $\mathrm{RT}$, wash for 15 minutes, BCCM
Remove PTM and add $400 \mu \mathrm{L}$ Agrobacterium, $\mathrm{OD}_{600}=2-2.5,30$ minutes resting at $\mathrm{RT}$, wash $2 \mathrm{x}$ for 5 minutes, WCCM $\left(4.3 \mathrm{gL}^{-1}\right.$ MS minerals, $103.1 \mathrm{mgL}^{-1}$ MS vitamins, $0.8 \mathrm{gL}^{-1}$

L-Cysteine, $0.5 \mathrm{gL}^{-1}$ Glutamine, $6 \mathrm{mgL}^{-1} 2,4-\mathrm{D}$, $15 \mathrm{gL}^{-1}$ Glucose, $15 \mathrm{gL}^{-1}$ Sucrose, $500 \mu \mathrm{M}$ Acetosyringone, $0.1 \mathrm{gL}^{-1}$ Casein hydrolysate, $\mathrm{pH}=$ 5.8)
Collect 25 precultivated IEs to $2.5 \mathrm{~mL} \mathrm{BCCM}$ (see barley for media composition). Remove BCCM and add $600 \mu \mathrm{L}^{-1}$ Agrobacterium $\mathrm{OD}_{600}=2.5-3,1$ minute 500 mbar, 10 minutes resting at RT, wash 1-2x for 5 minute, BCCM (see barley for media composition)
Collect up to 200 IEs in $1 \mathrm{~mL}$ IM ( $4 \mathrm{gL}^{-1}$ Chu N6 salt mixture, $4 \mathrm{mgL}^{-1} \mathrm{Chu}$ N6 vitamins, $0.7 \mathrm{gL}^{-1}$ L-Proline, $1.5 \mathrm{mgL}^{-1}$ 2,4-D, $36 \mathrm{gL}^{-1}$ Glucose, $68.4 \mathrm{gL}^{-1}$ Sucrose, $100 \mu \mathrm{M}$ Acetosyringone, $\mathrm{pH}=5.2$ ), wash $1 \mathrm{x}$, remove IM, add $1 \mathrm{ml}$ IM with Agrobacterium $\mathrm{OD}_{600}=0.7,5$ minutes resting at RT, blot IEs dry on 4 filter papers $(\varnothing 4.5 \mathrm{~cm})$

48-72 hours, 40 IEs on MCCM (2 gL ${ }^{-1}$ Chu N6 salt mixture, $2 \mathrm{mM} \mathrm{CaCl}_{2}$,

48-72 hours, 25 IEs as stack on filter paper $(\varnothing 4.5 \mathrm{~cm})$

48-72 hours in $2.5 \mathrm{~mL}$

Co-cultivation
BCCM (see inoculation for composition), $21^{\circ} \mathrm{C}$, dark soaked with $400 \mu \mathrm{L}$ WCCM

(see inoculation for

composition) + $100 \mathrm{mgL}^{-1} \mathrm{Larcoll}$, in petri dish $(\varnothing 5.5 \mathrm{~cm}), 21^{\circ} \mathrm{C}$, dark
48-72 hours, 25 IEs as stack on filter paper $(\varnothing 4.5 \mathrm{~cm})$ soaked with $300 \mu \mathrm{L}$ BCCM (see barley for composition), in petri dish (ø $5.5 \mathrm{~cm}), 21^{\circ} \mathrm{C}$, dark
$112 \mathrm{mgL}^{-1}$ B5 vitamins, $0.4 \mathrm{gL}^{-1}$ L-Cysteine, $2.9 \mathrm{gL}^{-1} \mathrm{~L}$-Proline, $4.4 \mathrm{mgL}^{-1}$ Dicamba, $37.6 \mathrm{gL}^{-1}$ Maltose $\cdot \mathrm{H}_{2} \mathrm{O}$, $100 \mu \mathrm{M}$ Acetosyringone, $1 \mathrm{mM}$ DTT, $0.5 \mathrm{gL}^{-1} \mathrm{MES}$, $\mathrm{pH}=5.8,4 \mathrm{gL}^{-1}$ Phytagel), $21^{\circ} \mathrm{C}$, dark 
TABle 1: Continued.

\begin{tabular}{|c|c|c|c|c|}
\hline Treatment/Step & Barley & Wheat & Triticale & Maize \\
\hline Callus induction & $\begin{array}{l}10 \mathrm{IEs} \text { each for } 2 \mathrm{x} 14 \mathrm{~d} \text { on } \\
\mathrm{BCIM}\left(4.3 \mathrm{gL}^{-1} \mathrm{MS}\right. \\
\text { minerals, } 5 \mu \mathrm{M} \mathrm{CuSO}_{4} \text {, } \\
1 \mathrm{mgL}^{-1} \text { Thiamine } \mathrm{HCl} \text {, } \\
0.69 \mathrm{gL}^{-1} \mathrm{~L} \text {-Proline, } \\
2.5 \mathrm{mgL}^{-1} \text { Dicamba, } \\
30 \mathrm{gL}^{-1} \text { Maltose } \cdot \mathrm{H}_{2} \mathrm{O}, \\
1 \mathrm{gL}^{-1} \text { Casein hydrolysate, } \\
0.25 \mathrm{gL}^{-1} \mathrm{Myo} \text {-inositol, } \mathrm{pH} \\
=5.8,3 \mathrm{gL}^{-1} \text { Phytagel, } \\
\left.150 \mathrm{mgL}^{-1} \text { Timentin }\right)+ \\
50 \mathrm{mgL}^{-1} \text { Hygromycin, } \\
24^{\circ} \mathrm{C} \text {, dark }\end{array}$ & 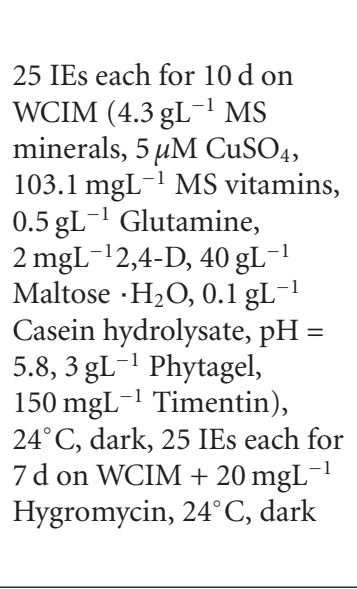 & $\begin{array}{l}10 \text { IEs each for } 14 \mathrm{~d} \text { on } \\
\text { BCIM (see barley for } \\
\text { composition) without } \\
\text { Hygromycin, } 24^{\circ} \mathrm{C} \text {, dark, } \\
14 \mathrm{~d} \text { on BCIM }+25 \mathrm{mgL}^{-1} \\
\text { Hygromycin, } 24^{\circ} \mathrm{C} \text {, dark }\end{array}$ & $\begin{array}{l}40 \mathrm{IEs} \text { each for } 7 \mathrm{~d} \text { on } \\
\text { MCIM ( } 4 \mathrm{gL}^{-1} \mathrm{Chu} \mathrm{N} \text { salt } \\
\text { mixture, } 2 \mathrm{mM} \mathrm{CaCl}_{2}, 5 \mu \mathrm{M} \\
\text { silver nitrate, } 112 \mathrm{mgL}^{-1} \mathrm{~B} 5 \\
\text { vitamins, } 2.9 \mathrm{gL}^{-1} \\
\mathrm{~L} \text {-Proline, } 4.4 \mathrm{mgL}^{-1} \\
\text { Dicamba, } 34.2 \mathrm{gL}^{-1} \\
\text { Sucrose, } 0.1 \mathrm{gL}^{-1} \text { Casein } \\
\text { hydrolysate, } 0.5 \mathrm{gL}^{-1} \mathrm{MES} \text {, } \\
\mathrm{pH}=5.8,4 \mathrm{gL}^{-1} \text { Phytagel, } \\
150 \mathrm{mgL}^{-1} \text { Timentin), } 20 \\
\text { IEs each for } 14 \mathrm{~d} \text { on } \mathrm{MCIM} \\
+1.5 \mathrm{mgL}^{-1} \text { Bialaphos, } \\
4-7 \mathrm{x} 14 \mathrm{~d} \text { on MCIM }+ \\
3 \mathrm{mgL}-1 \text { Bialaphos, } 24{ }^{\circ} \mathrm{C}, \\
\text { dark }\end{array}$ \\
\hline Shoot formation & 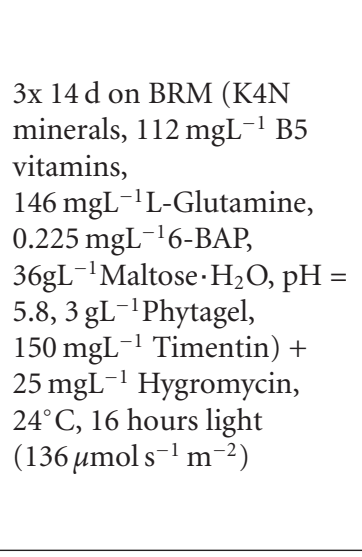 & see barley & see barley & $\begin{array}{l}\text { 6-10 calluses for } 7 \mathrm{~d} \text { on } \\
\mathrm{MRM}\left(4.3 \mathrm{gL}^{-1} \mathrm{MS}\right. \\
\text { minerals, } 2 \mathrm{mM} \mathrm{CaCl}_{2} \text {, } \\
103.1 \mathrm{mgL}^{-1} \mathrm{MS} \text { vitamins, } \\
60 \mathrm{gL}^{-1} \text { Sucrose, } \\
0.1 \mathrm{gL}^{-1} \mathrm{Myo}^{-i n o s i t o l, ~} \mathrm{pH}= \\
5.8,3 \mathrm{gL}^{-1} \text { Phytagel, } \\
\left.75 \mathrm{mgL}^{-1} \text { Timentin }\right)+ \\
1.5 \mathrm{mgL}^{-1} \text { Bialaphos, } 24^{\circ} \mathrm{C} \text {, } \\
\text { dark, } 2 \times 14 \text { d on } \mathrm{MRM}+ \\
1.5 \mathrm{mgL}^{-1} \text { Bialaphos, in } \\
\text { high petri dishes } \\
(100 \times 20 \mathrm{~mm}), 24^{\circ} \mathrm{C}, 16 \\
\text { hours light } \\
\left(170 \mu \mathrm{mol} \mathrm{s}^{-1} \mathrm{~m}^{-2}\right)\end{array}$ \\
\hline Plantlet formation & $\begin{array}{l}\text { Each plant for } 14-28 \mathrm{~d} \text { on } \\
\text { BRM }+25 \mathrm{mgL}^{-1} \\
\text { Hygromycin, in culture } \\
\text { vessels (see maize), } 24^{\circ} \mathrm{C} \text {, } \\
16 \text { hours light } \\
\left(136 \mu \mathrm{mol} \mathrm{s}^{-1} \mathrm{~m}^{-2}\right)\end{array}$ & see barley & see barley & $\begin{array}{l}6 \text { plants for } 7-14 \mathrm{~d} \text { on } \\
\text { MRM (half strength } \\
\text { sucrose compared to shoot } \\
\text { formation), in culture } \\
\text { vessels }(107 \times 94 \times 96 \mathrm{~mm}) \text {, } \\
24^{\circ} \mathrm{C}, 16 \text { hours light } \\
\left(170 \mu \mathrm{mol} \mathrm{s}^{-1} \mathrm{~m}^{-2}\right)\end{array}$ \\
\hline $\begin{array}{l}\text { Plant } \\
\text { establishment in } \\
\text { soil }\end{array}$ & $\begin{array}{l}\text { 5-6 weeks in substrate mix } \\
\text { (Spezialmischung } \\
\text { Petuniensubstrat, } \\
\text { Klasmann, Germany), } 40 \mathrm{~g} \\
\text { fertiliser "Osmocote" } \\
\text { (Scotts, Netherlands) per } \\
7.5 \mathrm{~L} \text { pot, } 14 / 12^{\circ} \mathrm{C} \\
\text { day/night, } 12 \text { hours light } \\
\left(136 \mu \mathrm{mol} \mathrm{s}{ }^{-1} \mathrm{~m}^{-2}\right)\end{array}$ & see barley & see barley & $\begin{array}{l}\text { 2-4 weeks in "Substrat 2" } \\
\text { (Klasmann, Germany), } \\
22 / 20^{\circ} \mathrm{C} \text { day/night, } 16 \\
\text { hours light } \\
\left(170 \mu \mathrm{mol} \mathrm{s}^{-1} \mathrm{~m}^{-2}\right)\end{array}$ \\
\hline
\end{tabular}

For the preparation of solid media, one volume of fourfold concentrated solution was mixed with three volumes of adequately concentrated Phytagel (Sigma, Germany) that had been autoclaved with the respective proportion of distilled water. If not stated otherwise standard $9-\mathrm{cm}$ petri dishes (Greiner, Germany) were used.

2.4. Isolation of Immature Embryos and Co-cultivation with A. tumefaciens. For the isolation of immature embryos (IEs) and their subsequent co-cultivation with A. tumefaciens, the following materials are needed.

(1) Forceps, scalpel, spatula, and preparation needles.

(2) Preparation microscope.

(3) 6-well cell culture plates (Greiner, Germany).

(4) Petri dishes (ø5.5 cm, Greiner, Germany). 
(5) Pipettes and disposable tips (200-1000 $\mu \mathrm{L}$ and 1000$5000 \mu \mathrm{L}$, autoclaved).

(6) Eppendorf tubes (2 mL, autoclaved, Eppendorf, Germany).

(7) Filter paper (several sizes, autoclaved, Millipore, Germany).

(8) Exsiccator and vacuum pump.

(9) Magnetic stirrer.

\section{Procedures}

3.1. Isolation of Immature Embryos. In barley, wheat, and triticale, developing caryopses were harvested $12-16 \mathrm{~d}$ post pollination, immersed for 3 minutes in 70\% ethanol, incubated in $5 \%$ sodium hypochlorite supplemented with $0.1 \%$ Tween for 15 minutes and washed five times in sterile, distilled water.

Barley IEs were excised from the caryopses by using forceps and a lanzet needle (see Note 5). The embryo axes of the IEs were removed. The IEs were transferred into $2.5 \mathrm{~mL}$ liquid BCCM (Table 1) in a 6-well plate with up to 50 IEs per well (see Notes 6-8).

Triticale and wheat IEs were excised as described for barley, yet without removal of the embryo axes. Fifty IEs were placed per petri dish with the scutellum facing up on TPCM or WPCM, respectively (Table 1).

Maize ears were harvested 10-14 d after pollination when IEs were of 1.5-2.5 mm in length. For surface sterilization the ears were first incubated 5 minutes in $70 \%$ ethanol, then in $2.4 \%$ sodium hypochlorite supplemented with $0.1 \%$ Tween for 20 minutes and finally washed 4 times in sterile distilled water for 5 minutes each. After removing the abaxial top of the kernels with a scalpel, IEs were dissected with a lancet and up to 200 collected in a $2-\mathrm{mL}$ tube containing $1 \mathrm{~mL}$ IM (Table 1).

3.2. Growth of Agrobacterium and Co-cultivation of Immature Embryos. A. tumefaciens strain LBA4404 was grown in $10 \mathrm{~mL}$ of antibiotic-free CPY medium [34] overnight at $28^{\circ} \mathrm{C}$ in 100-mL Erlenmeyer flasks with shaking at $180 \mathrm{rpm}$ (see Note 9). A glycerol stock $(200 \mu \mathrm{L}$ from a growing culture with an $\mathrm{OD}_{600}$ of 2.0 and $200 \mu \mathrm{L}$ of $15 \%$ glycerol) stored at $-80^{\circ} \mathrm{C}$ was thawed and added to the medium so as to start the culture. In case of maize transformation, CPY medium was solidified with $8 \mathrm{~g} \mathrm{~L}^{-1}$ bacto agar prior to autoclaving supplemented with spectinomycin thereafter.

In barley BCCM (Table 1) was completely removed and $600 \mu \mathrm{L} \mathrm{A}$. tumefaciens culture was added per well. The plate was placed in an exsiccator and vacuum infiltrated for 1 minute at 500 mbar. Then it was kept for 10 minutes inside the laminar hood without agitation followed by a washing step using $2.5 \mathrm{~mL}$ of BCCM. For co-cultivation the embryos were left in $2.5 \mathrm{~mL}$ of BCCM per well and the plates were incubated at $21^{\circ} \mathrm{C}$ in the dark for $48-72$ hours without agitation.

In wheat 50 precultivated IEs were collected into one well of a 6-well plate and treated with $2.5 \mathrm{~mL}$ liquid PTM
(Table 1) for 2 to 4 hours at RT. After removal of PTM $600 \mu \mathrm{L}$ A. tumefaciens culture was added, and the plate kept for 30 minutes inside the laminar hood. After washing twice with $2.5 \mathrm{~mL}$ WCCM (Table 1) IEs were placed in two stacks of 25 IEs each in a small petri dishes $(\varnothing 5.5 \mathrm{~cm})$ on $4.5-\mathrm{cm}$ sterile filter paper disks soaked with $400 \mu \mathrm{L}$ WCCM containing $100 \mathrm{mg} \mathrm{L}^{-1}$ Larcoll and incubated at $21^{\circ} \mathrm{C}$ in the dark for $48-$ 72 hours (see Note 10 ).

In triticale 25 precultivated IEs were transferred into liquid BCCM (Table 1) right prior to co-cultivation (see Note 11). The following steps were conducted as described for barley except that the washed IEs were placed in stacks onto filter paper disks soaked with $300 \mu \mathrm{L}$ of BCCM as described for wheat.

For maize transformation A. tumefaciens was precultivated for 2-3 d on solid CPY with $100 \mathrm{mg} \mathrm{L}^{-1}$ spectinomycin at $21^{\circ} \mathrm{C}$ in the dark. On the day of transformation the Agrobacterium colonies were collected from the plate with a spatula, resuspended in IM (Table 1) and incubated 23 hours at $23^{\circ} \mathrm{C}$ and $100 \mathrm{rpm}$. $\mathrm{OD}_{600}$ was adjusted to 0.7 . For inoculation the collected IEs were washed once with $1 \mathrm{~mL}$ IM. Then $1 \mathrm{~mL}$ of Agrobacterium suspension was added and mixed by inverting the tube. After incubation of 5 minutes at room temperature the IEs were transferred to four dry 4.5$\mathrm{cm}$ filter paper disks to remove excess solution. Subsequently 40 IEs each were placed with the scutellum side up onto petri dishes containing MCCM (Table 1).

3.3. Callus Development, Regeneration, and Rooting. In barley 10 IEs were cultivated per petri dish containing BCIM (Table 1) (see Note 12). The IEs were placed onto the medium with the scutellum side facing down. Sealed petri dishes were incubated in the dark at $24^{\circ} \mathrm{C}$ for two weeks followed by a subcultivation on fresh medium for another two weeks.

In wheat 25 IEs per petri dish were cultivated containing WCIM (Table 1) and incubated at $24^{\circ} \mathrm{C}$ in the dark for $10 \mathrm{~d}$ the scutellum facing upwards. Next the IEs were incubated for another week on WCIM containing $20 \mathrm{mg} \mathrm{L}^{-1}$ hygromycin under the same conditions (see Note 13).

After co-cultivation, triticale embryos 10 each were transferred to petri dishes containing solid BCIM (Table 1) and cultivated for 2 weeks followed by subcultivation on fresh medium additionally supplemented with $25 \mathrm{mg} \mathrm{L}^{-1}$ hygromycin for another 2 weeks (see Note 14).

In maize 40 IEs were incubated first on MCIM (Table 1) at $24^{\circ} \mathrm{C}$ in the dark for $7 \mathrm{~d}$. For the first selection of two weeks they were transferred to MCIM containing $1.5 \mathrm{mg} \mathrm{L}^{-1}$ bialaphos (Molekula, Germany). In the second selection step 20 embryos were cultivated per dish on MCIM supplemented with $3 \mathrm{mg} \mathrm{L}^{-1}$ bialaphos. The medium was replaced every $14 \mathrm{~d}$ for up to three months until white, rapidly growing type II calluses emerged (see Note 15).

Four weeks after gene transfer, the barley and triticale calluses were plated onto BRM (Table 1) (see Note 16). The plates were incubated at $24^{\circ} \mathrm{C}$ under illumination at $136 \mu \mathrm{mol} \mathrm{s}{ }^{-1} \mathrm{~m}^{-2}$ photon flux density for 16 hours per day. BRM was replaced fortnightly until regenerants emerged. Plantlets with a leaf length of 2 to $3 \mathrm{~cm}$ were then individually 

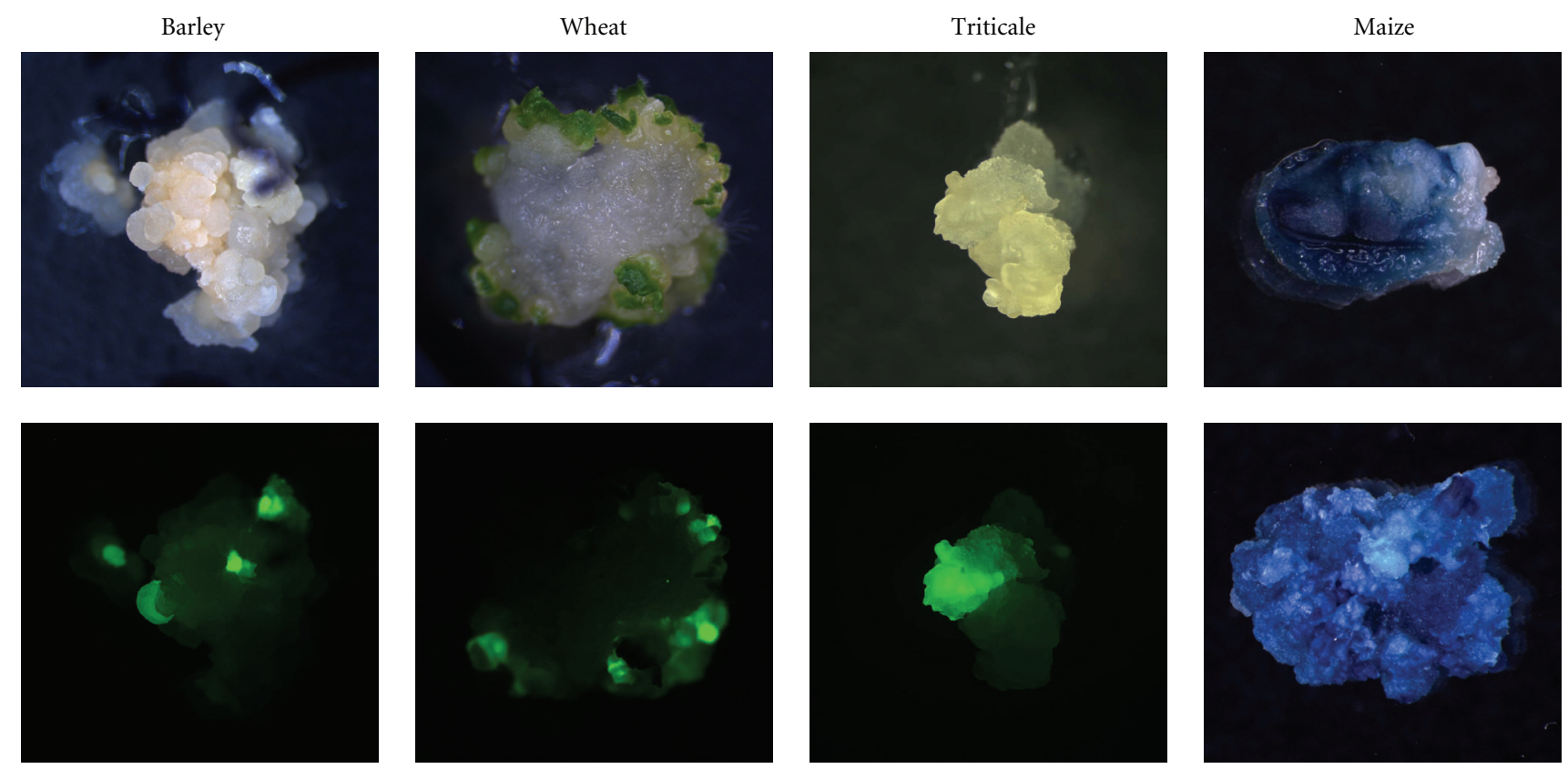

FIGURE 1: Reporter gene expression in immature embryo-derived calluses for three weeks (barley), four weeks (wheat), two weeks (triticale), $12 \mathrm{~d}$ (maize, upper picture) and 8 weeks (maize, lower picture) after co-culture. On the lower pictures of barley, wheat and triticale, the same objects are shown as above, but being exposed to far blue light and recorded with a GFP-filter set. The calluses of maize are shown following histochemical GUS assay [41].

grown in glass tubes ( $100 \mathrm{~mm}, \varnothing 25 \mathrm{~mm}$; Schütt, Germany) containing $4.5 \mathrm{~mL}$ of BRM (see Note 17). Rooted plants were transferred to the glasshouse where they grew to maturity under the same conditions as described for the donor plants.

The regeneration step for wheat was performed with 10 embryo-derived calluses per petri dish containing BRM (Table 1) (see Note 18) supplemented with $25 \mathrm{mg} \mathrm{L}^{-1}$ hygromycin for two weeks at $136 \mu \mathrm{mol} \mathrm{s} \mathrm{m}^{-1} \mathrm{~m}^{-2}$ photon flux density for 16 hours per day at $22^{\circ} \mathrm{C}$. The calluses showing green tissue were selected and again transferred to BRM and incubated under identical conditions for another $2 \mathrm{x} 14 \mathrm{~d}$ until shoot formation. Plantlets with a leaf length of 2 to $3 \mathrm{~cm}$ were treated like barley plants.

Segments of maize calluses with immature somatic embryos were placed first on MRM (Table 1) with $1.5 \mathrm{mg} \mathrm{L}^{-1}$ bialaphos for one week in the dark followed by another week incubation in the light with 16 hours photoperiod of $170 \mu \mathrm{mol} \mathrm{s}^{-1} \mathrm{~m}^{-2}$ photon flux density at $24^{\circ} \mathrm{C}$. Matured somatic embryos were removed from the callus under a preparation microscope and incubated in high petri dishes $(100 \times 20 \mathrm{~mm}$, Greiner, Germany) containing MRM supplemented with $1.5 \mathrm{mg} \mathrm{L}^{-1}$ bialaphos for a further two weeks until plantlets were formed. These plantlets were grown in culture vessels $(107 \times 94 \times 96$, SteriVent high, Duchefa, The Netherlands) with MRM (Table 1) for up to $14 \mathrm{~d}$ until they reached a size of approximately $10 \mathrm{~cm}$. Then they were potted into soil (Substrat 2, Klasmann, Germany) and cultivated as described for the donor plants.

3.4. Analysis of Transgenic Material. In order to facilitate the evaluation of the gene transfer and regeneration process,
TABLE 2: PCR-Primer used for the analysis of transgenic plants.

\begin{tabular}{ll}
\hline Primer & Sequence $5^{\prime}-3^{\prime}$ \\
\hline GH-Hpt-F1 & GAT CGG ACG ATT GCG TCG CA \\
GH-Hpt-R2 & TAT CGG CAC TTT GCA TCG GC \\
GH-Gfp-F1 & GGT CAC GAA CTC CAG CAG GA \\
GH-Gfp-R1 & GAC CAC ATG AAG CAG CAC GA \\
GH-Gfp-R2 & TAC GGC AAG CTG ACC CTG AA \\
GH-Gus-F1 & CCG GTT CGT TGG CAA TAC TC \\
GH-Gus-R1 & CGC AGC GTA ATG CTC TAC AC \\
GH-Ubi-F1 & TTC CGC AGA CGG GAT CGA TCT AGG \\
\hline
\end{tabular}

reporter genes were used instead of effector genes during the period of method establishment (Figure 1). For PCR analysis, genomic DNA from approximately $100 \mathrm{mg}$ of leaf material stored in liquid nitrogen was isolated by means of commercially available extraction kits (e.g., DNAzol, Invitrogen, Germany) according to the manufacturer's instructions. Standard PCR reactions with the appropriate primers (Table 2) were performed using $100 \mathrm{ng}$ genomic DNA per candidate plant. The PCR products were visualised following gel electrophoresis (Figure 2).

Plants which had proven PCR-positive were further analysed by Southern blot for transgene integration and copy number (data not shown). To this end, high quality DNA was prepared as described by Pallotta et al. [42]. Twenty five $\mu \mathrm{g}$ genomic DNA was digested with the appropriate restriction enzyme and the obtained fragments were separated by gel electrophoresis and blotted onto a hybond $\mathrm{N}$ membrane 


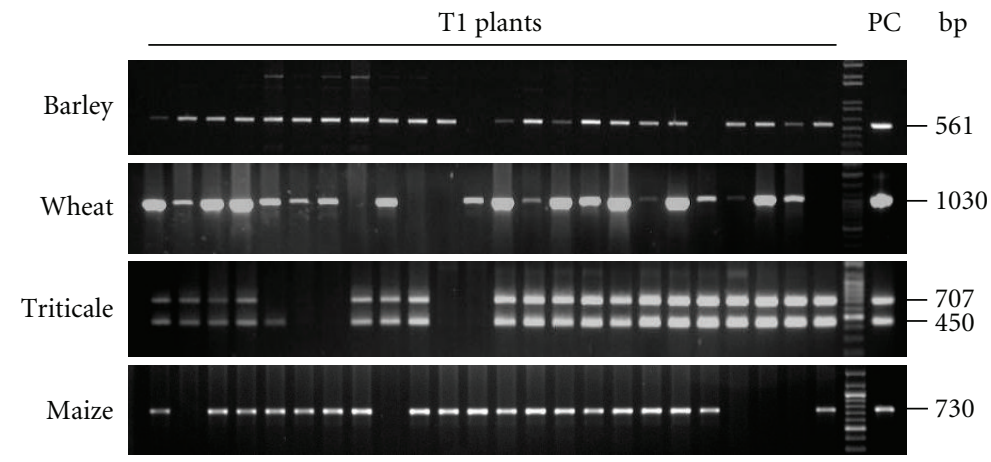

FIGURE 2: PCR analysis of progenies of primary transgenic plants. Twenty four plants of each T1 family were analysed for the presence of sgfp (barley, wheat, triticale, lower bands), Hpt (triticale, upper bands) or Gus (maize).

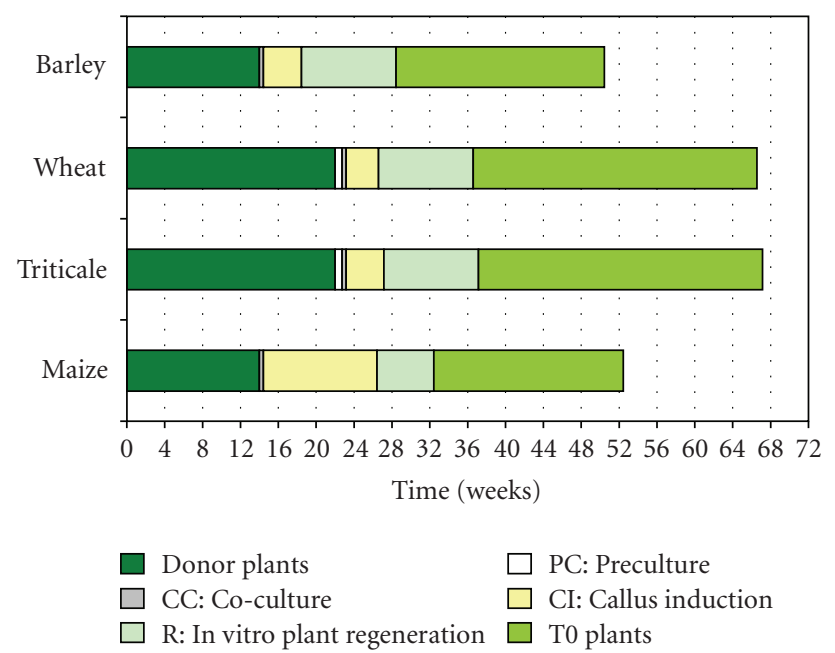

Figure 3: Time lines covering the entire transformation process from growing the donor plants until mature grains can be harvested from primary transgenic plants.

(Roche, Germany). Hybridisation of the blotted DNA with a gene-specific probe was done by labelling with DIG following the manufacturer's instructions (Roche, Germany).

Notes.

(1) The substrate mix is a special white peat substrate plus clay to ensure adequate $\mathrm{pH}$ buffering.

(2) Osmocote is a general long-term fertilizer that contains $19 \% \mathrm{~N}, 6 \% \mathrm{P}$ and $12 \% \mathrm{~K}$. Hakaphos Blau is a general fertilizer that contains $15 \% \mathrm{~N}, 10 \% \mathrm{P}$ and $15 \% \mathrm{~K}$. Hakaphos Grün is a general fertilizer that contains $20 \% \mathrm{~N}$, $5 \% \mathrm{P}$ and $10 \% \mathrm{~K}$.

(3) Substrate 2 consists of black and white peat. After germination plants are transferred to a substrate mix (compost, sand and white peat).

(4) Osmocote Pro is a general long-term fertilizer that contains $19 \% \mathrm{~N}, 7 \% \mathrm{P}$ and $10 \% \mathrm{~K}$.

(5) Notably, the developmental stage of the IEs is more crucial than their size. For the protocols described here, transition stage IEs that are about to turn from translucent to white colour are suited best.

(6) Contradictory results have been published regarding the effect of Acetosyringone on Agrobacterium-mediated transformation of immature barley embryos $[9,43,44]$. The addition of Acetosyringone results in increased transformation efficiency under the conditions described here.

(7) L-Cysteine supplemented to the co-culture medium was reported to prevent embryos from browning upon inoculation with Agrobacterium and to increase the transformation efficiency in soybean [45].

(8) In general, there is a risk to drop a plasmid when Agrobacterium is grown in the absence of antibiotics. However, in the protocol described here there was not any loss of vector detected, although Agrobacterium used for transformation was repeatedly checked via plasmid preparation. The advantage of growing Agrobacterium without antibiotics prior to inoculation is that the grown suspension can be directly used and the recipient cells are not exposed to any residual antibiotics.

(9) In barley, co-cultivation in liquid medium permits a substantially increased number of immature embryos to be processed at once, which results in a remarkable improvement in terms of efficiency [18].

(10) According to our experience, wheat IEs do not tolerate co-culture in liquid medium. On the other hand, it was shown earlier that wheat transformation efficiency can be improved through slight desiccation of IEs [3]. In the protocol presented here, gene transfer to wheat IEs is conducted on filter discs soaked with co-culture medium.

(11) Triticale IEs do not tolerate liquid co-culture as is the case in wheat.

(12) The increased $\mathrm{CuSO}_{4}$ concentration [46] results in improved formation of green plants compared to the conditions described by Tingay et al. [9].

(13) In wheat a resting period without selection following co-culture turned out to be crucial for the generation of transgenic lines.

(14) Although a comparatively low hygromycin concentration was used for cv. "Bogo", all regenerants obtained proved transgenic. 
(15) Depending on the genotype different callus types are recommended for manual selection [17].

(16) FHG medium has been successfully used for plant regeneration in a number of published experiments $[7,9,44$, 47]. Yet, a direct comparison conducted in our lab revealed that BRM (Table 1) is superior to FHG.

(17) Alternatively, as many as 16 plants can be grown per culture vessels (see maize) containing BRM. However, glass tubes are preferred to minimize the risk of cross contamination.

(18) Several media have been described for the selective development of transgenic wheat regenerants [3]. In our experiments selection worked best on BRM supplemented with hygromycin (Table 1).

\section{Conclusion}

In this paper, effective and reproducible protocols for the generation of stably transgenic barley, wheat, triticale and maize plants are presented. In comparison with the earlier reports several improvements have been implemented. The selection regimes utilized for all four species proved to ensure an almost exclusive regeneration of transgenic plants, which is valid for both hygromycin-based selection in barley, wheat and triticale as well as selection of transgenic maize which relies on bialaphos. The period of time needed for the entire process from growing donor plants until the harvest of mature grains from primary transgenic lines is between 51 weeks in spring barley and maize up to 66 weeks in winter wheat and triticale (Figure 3). The transformation efficiencies obtained by the methods described have been 20 $86 \%$ in barley, $2-10 \%$ in wheat, $2-4 \%$ in triticale and $0.5-$ $24 \%$ in maize. The presented protocols are suitable for comprehensive functional analyses of recombinant nucleotide sequences on a large scale. Furthermore, they constitute a powerful fundament for applied research aiming to improve, for example, disease resistance, tolerance towards abiotic stresses as well as product quality of cereal crops.

\section{Acknowledgments}

The authors thank C. Marthe, H. Büchner, S. Wolf and E. Grützemann for their excellent technical assistance. They also thank Dr. Sylvia Broeders for providing the vector pSB187. This work was in part funded by the German Research Foundation (Project KU 2265/1).

\section{References}

[1] http://faostat.fao.org.

[2] A. Repellin, M. Båga, P. P. Jauhar, and R. N. Chibbar, "Genetic enrichment of cereal crops via alien gene transfer: new challenges," Plant Cell, Tissue and Organ Culture, vol. 64, no. 2-3, pp. 159-183, 2001.

[3] H. D. Jones, "Wheat transformation: current technology and applications to grain development and composition," Journal of Cereal Science, vol. 41, no. 2, pp. 137-147, 2005.

[4] A. K. Shrawat and H. Lörz, "Agrobacterium-mediated transformation of cereals: a promising approach crossing barriers," Plant Biotechnology Journal, vol. 4, no. 6, pp. 575-603, 2006.
[5] S. Goedeke, G. Hensel, E. Kapusi, M. Gahrtz, and J. Kumlehn, "Transgenic barley in fundamental research and biotechnology," Transgenic Plant Journal, vol. 1, no. 1, pp. 104-117, 2007.

[6] J. Kumlehn, G. Zimmermann, C. Berger, C. Marthe, and G. Hensel, "Characters of transgenic plants and their application in plant production-triticeae cereals," in Genetic Modification of Plants-Agriculture, Horticulture \& Forestry, Springer, Berlin, Germany, 2009.

[7] Y. Hiei, S. Ohta, T. Komari, and T. Kumashiro, "Efficient transformation of rice (Oryza sativa L.) mediated by Agrobacterium and sequence analysis of the boundaries of the T-DNA," The Plant Journal, vol. 6, no. 2, pp. 271-282, 1994.

[8] Y. Ishida, H. Saito, S. Ohta, Y. Hiei, T. Komari, and T. Kumashiro, "High efficiency transformation of maize (Zea mays L.) mediated by Agrobacterium tumefaciens," Nature Biotechnology, vol. 14, no. 6, pp. 745-750, 1996.

[9] S. Tingay, D. McElroy, R. Kalla, et al., "Agrobacterium tumefaciens-mediated barley transformation," The Plant Journal, vol. 11, no. 6, pp. 1369-1376, 1997.

[10] M. Cheng, J. E. Fry, S. Pang, et al., "Genetic transformation of wheat mediated by Agrobacterium tumefaciens," Plant Physiology, vol. 115, no. 3, pp. 971-980, 1997.

[11] J. Kumlehn, L. Serazetdinova, G. Hensel, D. Becker, and H. Loerz, "Genetic transformation of barley (Hordeum vulgare L.) via infection of androgenetic pollen cultures with Agrobacterium tumefaciens," Plant Biotechnology Journal, vol. 4, no. 2, pp. 251-261, 2006.

[12] I. B. Holme, H. Brinch-Pedersen, M. Lange, and P. B. Holm, "Transformation of barley (Hordeum vulgare L.) by Agrobacterium tumefaciens infection of in vitro cultured ovules," Plant Cell Reports, vol. 25, no. 12, pp. 1325-1335, 2006.

[13] C. L. Armstrong, J. Romero-Severson, and T. K. Hodges, "Improved tissue culture response of an elite maize inbred through backcross breeding, and identification of chromosomal regions important for regeneration by RFLP analysis," TAG Theoretical and Applied Genetics, vol. 84, no. 5-6, pp. 755762, 1992.

[14] X. Huang and Z. Wei, "Successful Agrobacterium-mediated genetic transformation of maize elite inbred lines," Plant Cell, Tissue and Organ Culture, vol. 83, no. 2, pp. 187-200, 2005.

[15] A. Valdez-Ortiz, S. Medina-Godoy, M. E. Valverde, and O. Paredes-López, "A transgenic tropical maize line generated by the direct transformation of the embryo-scutellum by $A$. tumefaciens," Plant Cell, Tissue and Organ Culture, vol. 91, no. 3, pp. 201-214, 2007.

[16] B. R. Frame, J. M. McMurray, T. M. Fonger, et al., "Improved Agrobacterium-mediated transformation of three maize inbred lines using MS salts," Plant Cell Reports, vol. 25, no. 10, pp. 1024-1034, 2006.

[17] Y. Ishida, Y. Hiei, and T. Komari, "Agrobacterium-mediated transformation of maize," Nature Protocols, vol. 2, no. 7, pp. 1614-1621, 2007.

[18] G. Hensel, V. Valkov, J. Middlefell-Williams, and J. Kumlehn, "Efficient generation of transgenic barley: the way forward to modulate plant-microbe interactions," Journal of Plant Physiology, vol. 165, no. 1, pp. 71-82, 2008.

[19] J. Zimny, D. Becker, R. Brettschneider, and H. Lörz, "Fertile, transgenic Triticale (x Triticosecale Wittmack)," Molecular Breeding, vol. 1, no. 2, pp. 155-164, 1995.

[20] S. Oleszczuk, S. Sowa, and J. Zimny, "Direct embryogenesis and green plants regeneration from isolated microspores of hexaploid triticale (x Triticosecale Wittmack) cv. Bogo," Plant Cell Reports, vol. 22, no. 12, pp. 885-893, 2004. 
[21] S. Sowa, S. Oleszczuk, and J. Zimny, "A simple and efficient method for cryopreservation of embryogenic triticale calli," Acta Physiologiae Plantarum, vol. 27, no. 2, pp. 237-243, 2005.

[22] E. E. Hood, G. L. Helmer, R. T. Fraley, and M. D. Chilton, "The hypervirulence of Agrobacterium tumefaciens A281 is encoded in a region of pTiBo542 outside of T-DNA," Journal of Bacteriology, vol. 168, no. 3, pp. 1291-1301, 1986.

[23] P. R. Matthews, M.-B. Wang, P. M. Waterhouse, et al., "Marker gene elimination from transgenic barley, using cotransformation with adjacent 'twin T-DNAs' on a standard Agrobacterium transformation vector," Molecular Breeding, vol. 7, no. 3, pp. 195-202, 2001.

[24] M. Lange, E. Vincze, M. G. Møller, and P. B. Holm, "Molecular analysis of transgene and vector backbone integration into the barley genome following Agrobacterium-mediated transformation," Plant Cell Reports, vol. 25, no. 8, pp. 815-820, 2006.

[25] B. Weir, X. Gu, M. Wang, N. Upadhyaya, A. R. Elliott, and R. I. S. Brettell, "Agrobacterium tumefaciens-mediated transformation of wheat using suspension cells as a model system and green fluorescent protein as a visual marker," Australian Journal of Plant Physiology, vol. 28, no. 8, pp. 807$818,2001$.

[26] H. Wu, C. Sparks, B. Amoah, and H. D. Jones, "Factors influencing successful Agrobacterium-mediated genetic transformation of wheat," Plant Cell Reports, vol. 21, no. 7, pp. 659$668,2003$.

[27] M.-J. Coronado, G. Hensel, S. Broeders, I. Otto, and J. Kumlehn, "Immature pollen-derived doubled haploid formation in barley cv. Golden Promise as a tool for transgene recombination," Acta Physiologiae Plantarum, vol. 27, no. 4, pp. 591-599, 2005.

[28] A. Hoekema, P. R. Hirsch, P. J. J. Hooykaas, and R. A. Schilperoort, "A binary plant vector strategy based on separation of vir- and T-region of the Agrobacterium tumefaciens Tiplasmid," Nature, vol. 303, no. 5913, pp. 179-180, 1983.

[29] H. K. Khanna and G. E. Daggard, "Agrobacterium tumefaciens transformation of wheat using a superbinary vector and a polyamine-supplemented regeneration medium," Plant Cell Reports, vol. 21, no. 5, pp. 429-436, 2003.

[30] S. G. Jin, T. Komari, M. P. Gordon, and E. W. Nester, "Genes responsible for the supervirulence phenotype of Agrobacterium tumefaciens A281," Journal of Bacteriology, vol. 169, no. 10, pp. 4417-4425, 1987.

[31] T. Komori, T. Imayama, N. Kato, Y. Ishida, J. Ueki, and T. Komari, "Current status of binary vectors and superbinary vectors," Plant Physiology, vol. 145, no. 4, pp. 1155-1160, 2007.

[32] Y. Itoh, J. M. Watson, D. Haas, and T. Leisinger, "Genetic and molecular characterization of the Pseudomonas plasmid pVS1," Plasmid, vol. 11, no. 3, pp. 206-220, 1984.

[33] A. Himmelbach, U. Zierold, G. Hensel, et al., "A set of modular binary vectors for transformation of cereals," Plant Physiology, vol. 145, no. 4, pp. 1192-1200, 2007.

[34] T. Komari, Y. Hiei, Y. Saito, N. Murai, and T. Kumashiro, "Vectors carrying two separate T-DNAs for co-transformation of higher plants mediated by Agrobacterium tumefaciens and segregation of transformants free from selection markers," The Plant Journal, vol. 10, no. 1, pp. 165-174, 1996.

[35] W.-L. Chiu, Y. Niwa, W. Zeng, T. Hirano, H. Kobayashi, and J. Sheen, "Engineered GFP as a vital reporter in plants," Current Biology, vol. 6, no. 3, pp. 325-330, 1996.

[36] A. H. Christensen and P. H. Quail, "Ubiquitin promoter-based vectors for high-level expression of selectable and/or screenable marker genes in monocotyledonous plants," Transgenic Research, vol. 5, no. 3, pp. 213-218, 1996.
[37] L. Hausmann and R. Töpfer, "Entwicklung von PlasmidVektoren,” Vorträge für Pflanzenzüchtung, vol. 45, pp. 153-171, 1999.

[38] CAMBIA, Australia, http://www.cambia.org.au.

[39] T. Murashige and F. Skoog, "A revised medium for rapid growth and bioassays with tobacco tissue cultures," Physiologia Plantarum, vol. 15, no. 3, pp. 473-497, 1962.

[40] C. C. Chu, C. C. Wang, C. S. Sun, C. Hus, K. C. Yin, and C. Y. Chu, "Establishment of an efficient medium for another culture of rice through comparative experiments on the nitrogen sources," Scientia Sinica, vol. 18, pp. 659-668, 1975.

[41] R. A. Jefferson, "Assaying chimeric genes in plants: the GUS gene fusion system," Plant Molecular Biology Reporter, vol. 5, no. 4, pp. 387-405, 1987.

[42] M. A. Pallotta, R. D. Graham, P. Langridge, D. H. B. Sparrow, and S. J. Barker, "RFLP mapping of manganese efficiency in barley," TAG Theoretical and Applied Genetics, vol. 101, no. 7, pp. 1100-1108, 2000.

[43] M. Patel, J. S. Johnson, R. I. S. Brettell, J. Jacobsen, and G.-P. Xue, "Transgenic barley expressing a fungal xylanase gene in the endosperm of the developing grains," Molecular Breeding, vol. 6, no. 1, pp. 113-124, 2000.

[44] Y.-D. Fang, C. Akula, and F. Altpeter, "Agrobacteriummediated barley (Hordeum vulgare L.) transformation using green fluorescent protein as a visual marker and sequence analysis of the T-DNA::barley genomic DNA junctions," Journal of Plant Physiology, vol. 159, no. 10, pp. 1131-1138, 2002.

[45] P. M. Olhoft and D. A. Somers, "L-cysteine increases Agrobacterium-mediated T-DNA delivery into soybean cotyledonarynode cells," Plant Cell Reports, vol. 20, no. 8, pp. 706-711, 2001.

[46] A. Trifonova, S. Madsen, and A. Olesen, "Agrobacteriummediated transgene delivery and integration into barley under a range of in vitro culture conditions," Plant Science, vol. 161, no. 5, pp. 871-880, 2001.

[47] Y. Wan and P. G. Lemaux, "Generation of large numbers of independently transformed fertile barley plants," Plant Physiology, vol. 104, no. 1, pp. 37-48, 1994. 

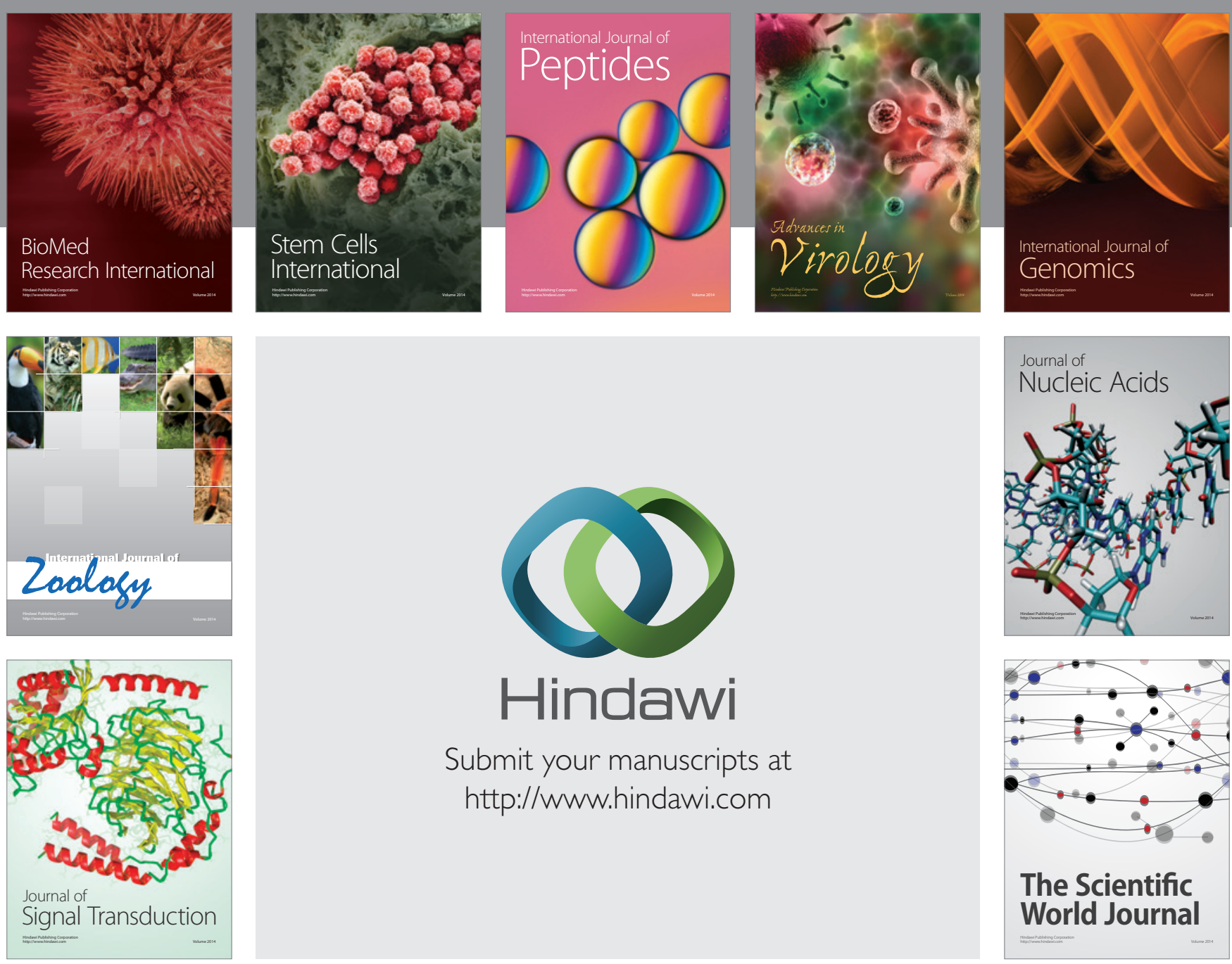

Submit your manuscripts at

http://www.hindawi.com
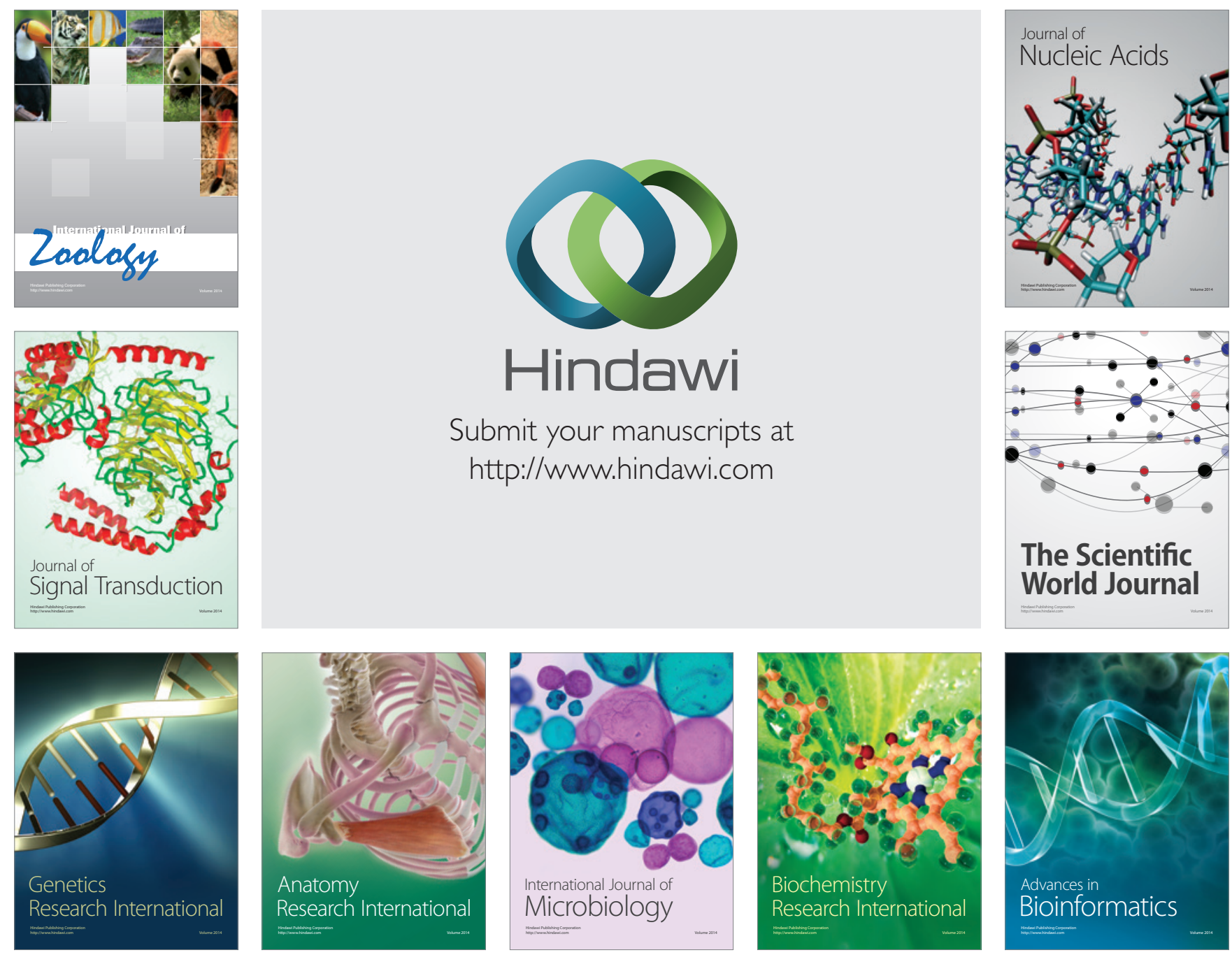

The Scientific World Journal
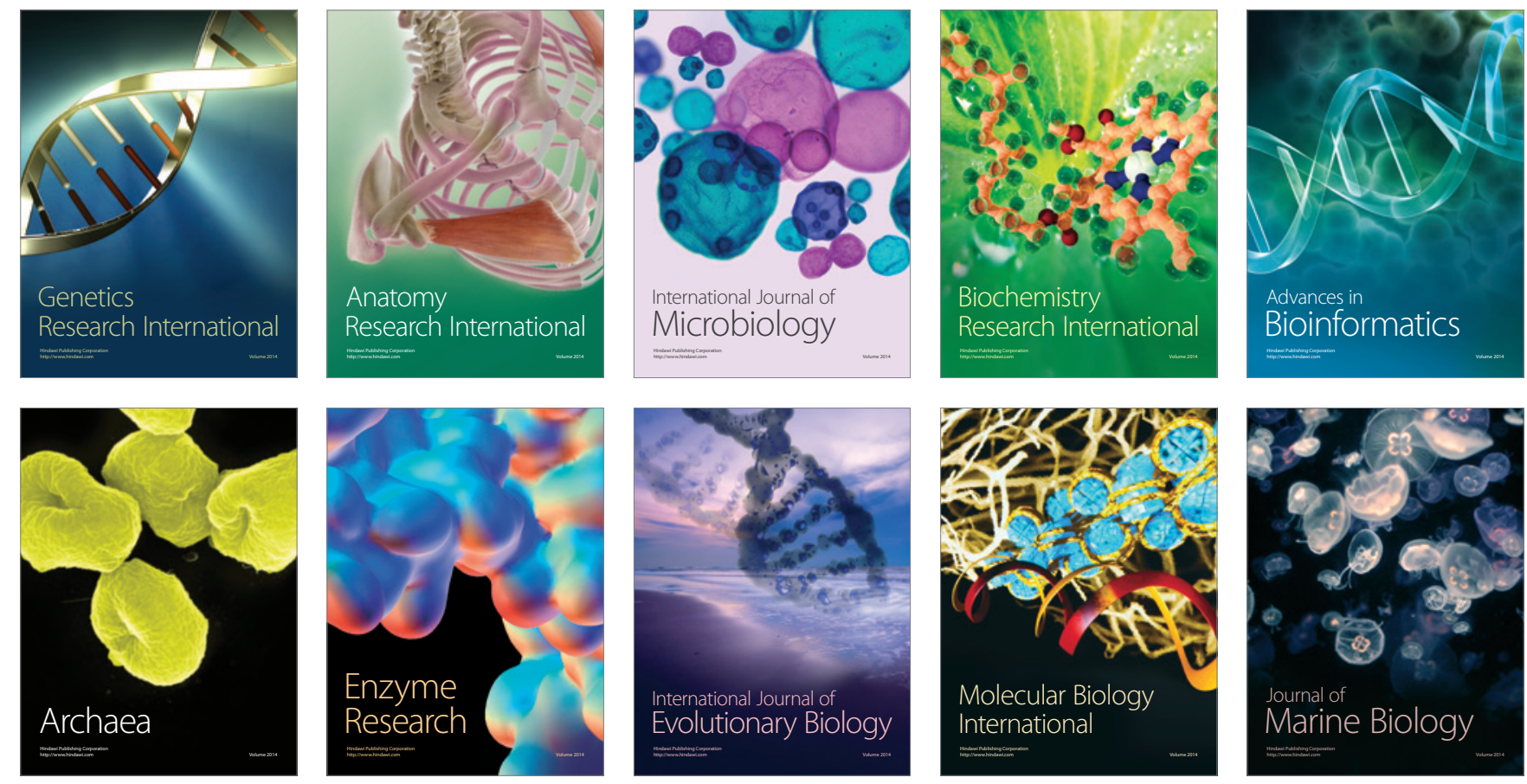